\title{
NGARUWAT SOLOKAN DI DESA GIHDEUNG KECAMATAN PARONGPONG KABUPATEN BANDUNG BARAT
}

\author{
Oleh Lina Herlinawati
}

\author{
Balai Pelestarian Sejarah dan Nilai Tradisional Bandung \\ Jl. Cinambo No. 136 Ujungberung Bandung \\ Email: lina.emul000@yahoo.co.id
}

Naskah disetujui: 29 Mei 2011

\begin{abstract}
Abstrak
Pelaksanaan upacara tradisional suatu masyarakat pada umumnya sangat menarik untuk diteliti, karena memiliki keunikan, kesakralan, dan nilai-nilai moral yang terkandung di dalamnya. Hal itulah yang mendorong penulis untuk mengunjungi masyarakat Cihideung di Kabupaten Bandung Barat, yang hingga kini setiap tahun masih melaksanakan upacara tradisional yang berkaitan dengan pertanian, yaitu Ngaruat Solokan atau Hajat Cai. Upacara yang merupakan sisa kepercayaan leluhur dan masih diyakini mereka adalah tradisi ritual untuk memelihara mata air dan selokan. Mereka memohon kepada Allah, karuhun, dan penunggu mata air, agar air selalu dalam keadaan lancar. Mereka pun sangat bersyukur dengan limpahan air, yang membuat mereka bisa bercocok tanam serta memenuhi kebutuhan sehari-hari hingga kini. Penelitian yang dilakukan bersifat deskriptif dengan metode kualitatif. Dari pelaksanaan upacara tersebut terkandung berbagai macam norma serta nilai budaya yang berguna untuk mengukuhkan rasa solidaritas atau kebersamaan antarsesama warga masyarakat, yaitu nilai-nilai religius, sosial, ekonomi, pendidikan, dan rekreatif.
\end{abstract}

Kata kunci: pertanian, mata air, Ngaruat Solokan.

\section{Abstract}

Traditional ceremonies are interesting things to study because they are unique, sacred, and have moral values. Ngaruat solokan or hajat cai is a kind of ceremony that is conducted every year by Cihideung people in Kabupaten Bandung Barat. The ceremony is a remnant of ancestral beliefs and perceived as ritual tradition to preserve springs and streams. The people request for the mercy of God, ancestors and the spirit of the spring asking the water to be in abundance. They would be grateful for the abundance of the water that makes them cultivate and fulfill their daily needs up 
to this day. Solidarity can be built through this kind of ceremony, e.g. religious, social, economical, educational and recreational values. This is a descriptive research with qualitative method.

Keywords: agriculture, spring, Ngaruat Solokan

\section{A. PENDAHULUAN}

Masyarakat Indonesia, khususnya masyarakat Jawa Barat adalah masyarakat agraris, yang sebagian besar masyarakatnya hidup dari hasil pertanian. Kegiatan pertanian (bercocok tanam) merupakan salah satu mata pencaharian dalam memenuhi kebutuhan hidupnya. Dalam sistem pertanian tersebut dikenal dua jenis pertanian, yaitu pertanian dengan sistem bercocok tanam di ladang dan pertanian dengan sistem bercocok tanam di sawah.

Sistem bercocok tanam di ladang, huma, atau sistem perladangan dilakukan di areal ladang tanpa irigasi teknis. Sistem perladangan ini di beberapa wilayah di Jawa Barat masih bisa dijumpai, terutama pada masyarakat tradisional atau masyarakat adat. Pertanian ladang ini bagi mereka merupakan mata pencaharian pokok dan bagian integral dari budayanya. Sistem pertanian dengan bercocok tanam di sawah sendiri merupakan salah satu bentuk pertanian yang relatif menetap, dan merupakan mata pencaharian masyarakat Sunda di Jawa Barat, khususnya di daerah pedesaan. Sistem bercocok tanam ini memerlukan sarana irigasi teknis untuk mengairi sawah, sehingga para petani dapat melakukan panen dua hingga tiga kali dalam setahun.

Perkembangan selanjutnya, dapat dikatakan lahan pertanian semakin berkurang seiring dengan laju pembangunan yang semakin gencar menggusur lahan pertanian yang subur untuk dijadikan pemukiman baru atau pabrik (industri). Akibatnya, nilainilai atau norma yang berlaku dalam masyarakat tani pun turut tergusur. Seperti halnya upacara-upacara yang berkaitan dengan pertanian akhirnya berkurang pendukungnya.

Berdasarkan pemikiran tersebut, maka upacara tradisional yang berkaitan dengan pertanian di suatu daerah - sebagai salah satu warisan kehidupan masyarakat tani masa silam, perlu untuk diteliti dan didokumentasikan sebelum terlindas arus modernisasi. Aktivitas upacara tradisional tersebut berkaitan erat dengan sistem kepercayaan masyarakat atau religi. Pada umumnya ditujukan untuk menghormati, mensyukuri, memuja, dan meminta keselamatan kepada roh-roh leluhur mereka yang berjasa dalam dunia pertanian.

Salah satunya adalah Upacara Ruwatan Solokan yang dilakukan masyarakat Cihideung di Kabupaten Bandung Barat. Dengan keunikan dan kekhasan upacara tradisional Ruwatan Solokan, penulis merasa tertarik untuk mengkajinya lebih jauh. Adapun judul penelitian yang penulis ambil adalah Ngaruwat Solokan di Desa Cihideung Kecamatan Parongpong Kabupaten Bandung Barat. Dari pelaksanaan upacara tradisional tersebut akan diamati bagaimana makna dan arti dari kegiatan upacara, simbol-simbol dalam upacara, arti dan fungsi upacara terhadap kehidupan mereka, dan sebagainya. 
Penelitian ini bertujuan untuk menggali tentang upacara tradisional pertanian yang masih dilakukan masyarakat Desa Cihideung di Kabupaten Bandung Barat serta memperkaya khazanah budaya, terutama budaya tradisional. Ruang lingkup penelitiannya meliputi ruang lingkup materi, yaitu berbagai hal yang berkaitan dengan upacara adat, seperti nama upacara, maksud dan tujuan upacara, waktu dan tempat penyelenggaraan upacara, pihakpihak yang terlibat upacara, persiapan dan perlengkapan upacara, jalannya upacara, pantangan-pantangan yang harus dipatuhi, serta makna yang terkandung dalam simbol upacara. Ruang lingkup wilayahnya sendiri adalah di Desa Cihideung, Kecamatan Parongpong, Kabupaten Bandung Barat, Provinsi Jawa Barat.

Penelitian yang digunakan bersifat deskriptif dengan metode kualitatif, yaitu suatu cara yang digunakan untuk menyelidiki dan memecahkan masalah yang tidak terbatas pada pengumpulan dan penyusunan data saja, tetapi meliputi analisis dan interpretasi data sampai pada kesimpulan yang didasarkan atas penelitian.

Terdapat beberapa konsep yang perlu diuraikan berkaitan dengan penelitian mengenai Ruwatan Solokan di Desa Cihideung. Konsep-konsep tersebut adalah tentang upacara, ngaruat. Menurut Rahmat Subagio dalam Ria Intani (2002:4), upacara khususnya upacara tradisional adalah kelakuan simbol manusia yang mengharapkan keselamatan, yang merupakan rangkaian tindakan yang diatur oleh adat yang berlaku, serta hubungan dengan berbagai macam peristiwa tetap yang biasa terjadi dalam masyarakat yang bersangkutan.
Sebagai tradisi, ruwatan sudah dikenal sejak jaman Hindu dan Budha, dari kata ruat yang artinya luwar atau lepas. Ruwatan berarti melepaskan segala bentuk malapetaka akibat perbuatan manusia atau keberadaan manusia yang tidak pada tempat atau kedudukannya, tataning ing ngaurip. Ruwatan merupakan doa atau ikhtiar yang harus dibarengi dengan langkahlangkah nyata menuju perbaikan (www. ratupelet.com/makna-ruwatan).

Dalam Kamus Umum Basa Sunda yang disusun LBSS (Lembaga Basa dan Sastra Sunda), ngaruat adalah mengadakan selamatan menolak bala. Selanjutnya Ruwatan atau ngaruat dalam bahasa Sunda pun ternyata merupakan kebiasaan yang bermakna sangat dalam. Ia juga bagian dari keyakinan sebagian masyarakat Sunda. Meski secara fisik, tradisi ini sudah jarang dipraktikkan. Ruwatan dianggap sakral dalam kehidupan. Konon, itu berkait dengan hidup matinya manusia, bahkan kesinambungan negeri dan alam semesta (ekorisanto.blogspot.com/2009/08/ ruwatan-dalam-budaya-sunda-1.html).

Sementara itu ngaruat atau diruat menurut Sang Pujangga Sunda, R.H. Hasan Mustofa, merupakan adat Sunda yang biasa disebut juga dengan dilokat, yang dilaksanakan jika ada seorang anak yang sedang sakit. Kemudian dalam tradisi Pantun, terdapat istilah ruatan taneuh, ngaruat hulu wotan, parit, danau, ngaruat kampung yang baru dibangun. Tujuan ngaruat tersebut adalah untuk memunculkan kembali kesucian sekaligus menolak unsur-unsurkejahatan. Semua unsur negatif harus diruat dengan melakukan ritual keselamatan (id-id.facebook.com/topic.php? uid $=270577024309$ ? topic $=46060$ ). 


\section{B. HASIL DAN BAHASAN}

Cihideung - Parongpong, identik dengan hamparan tanaman hias dengan aneka warna bunga. Memang, Desa Cihideung adalah salah satu desa di Kecamatan Parongpong yang dikenal sebagai salah satu sentra penjualan tanaman hias di Kabupaten Bandung Barat.

Secara adminstrasi, Desa Cihideung merupakan salah satu dari tujuh desa di Kecamatan Parongpong. Desa-desa lainnya adalah Desa Ciwaruga, Desa Cigugur Tengah, Desa Sariwangi, Desa Cihanjuang, Desa Cihanjuang Rahayu, dan Desa Karyawangi. Batasbatas wilayah Desa Cihideung adalah sebelah utara berbatasan dengan Perkebunan Teh Sukawana, Kecamatan Parongpong; sebelah selatan berbatasan dengan Isola, Kecamatan Sukasari; sebelah timur berbatasan dengan Desa Sukajaya dan Desa Gudang Kahuripan, Kecamatan Lembang; dan sebelah barat berbatasan dengan Desa Karyawangi dan Desa Cigugurgirang, Kecamatan Parongpong.

Desa Cihideung terletak cukupjauh dari ibukota Kabupaten Bandung Barat (yang sementara terletak di Kecamatan Batujajar), memiliki jarak sekitar $20 \mathrm{~km}$ dari ibu kota kabupaten, dan ditempuh sekitar 1 jam dengan menggunakan kendaraan bermotor apabila keadaan lalu lintas lancar. Dikatakan demikian, karena dalam keseharian sepanjang jalan ke arah Batujajar itu wilayahnya terdiri atas puluhan pabrik yang menyangkut ribuan karyawan. Hal itu berdampak pada kemacetan jalan yang dilalui aktivitas pabrik-pabrik tersebut.

Jarak Desa Cihideung ke ibu kota kecamatan sendiri terbilang dekat, yaitu sekitar $2 \mathrm{~km}$ dengan lama jarak tempuh sekitar 10 menit dengan menggunakan kendaraan bermotor. Kemudian jarak ke ibu kota provinsi, Kota Bandung, sekitar $15 \mathrm{~km}$ dengan lama jarak tempuh sekitar 1 jam menggunakan kendaraan bermotor.

Kondisi jalan menuju Desa Cihideung beraspal baik. Kendaraan umum berupa angkutan per desa/ kecamatan tersedia sebanyak 11 unit yang melewati wilayah Kecamatan Parongpong. Dari Terminal Parongpong yang tidak begitu jauh letaknya dari Desa Cihideung, tersedia angkutan desa/ kecamatan jurusan Parongpong - Cimahi dan Parongpong - Lembang. Ojek pun siap mengantar ke pelosok-pelosok dan tersedia hingga 350 unit dengan jumlah pangkalan ojek sebanyak 13 tempat, menyebar di wilayah Kecamatan Parongpong.

Luas wilayah Desa Cihideung 445,410 ha, dengan penggunaan sebagai berikut : luas pemukiman 201,000 ha, pekuburan 2.000 ha, pekarangan 40,249 ha perkantoran 0,155 ha, dan luas prasarana umum lainnya 11,243 ha. Cihideung memiliki bentangan wilayah berupa dataran tinggi/pegunungan dengan ketinggian 800 di atas permukaan laut (mdl) dan lereng gunung dengan tingkat kemiringan tanah $15^{\circ}$ s.d. $85^{\circ}$. Suhu udara rata-rata berkisar dari $17^{\circ} \mathrm{C}$ s.d. $24^{\circ} \mathrm{C}$. Curah hujan rata-rata antara 2.000 s.d. $5.000 \mathrm{~mm} /$ tahun dengan jumlah bulan hujan kelembaban selama 6 bulan.

Dengan kondisi alam yang sejuk didukung tanah yang subur merupakan anugrah bagi masyarakat Desa Cihideung. Hasil tanaman dari bumi yang subur didukung suasana alam yang hijau dan sejuk membuat Cihideung dikenal sebagai sentra tanaman hias. Begitu terkenalnya tanaman hias dari 
Cihideung, membuatnya menjadi tujuan wisata yang populer. Tak heran jika sebagian besar masyarakat Desa Cihideung mengandalkan tanaman hias sebagai sumber penghasilan utama mereka.

Selain penghasil tanaman hias, Desa Cihideung pun dikenal sebagai daerah pertanian tanaman pangan, seperti jagung, ubi-ubian (ubi kayu, ubi jalar), sayuran seperti cabe, tomat, sawi, buncis, brocoli, dan cabe siam; serta tanaman buah-buahan yang dibudidayakan, seperti alpukat, pepaya, dan pisang. Tak hanya terkenal dengan hasil pertaniannya, Cihideung pun memiliki andalan dari peternakan. Jenis populasi ternaknya adalah sapi, ayam kampung, jenis ayam boiler, kuda, domba, kelinci, anjing, dan kucing. Dari ternak sapi perah dihasilkan susu, yang dijual ke KUD atau konsumen langsung.

\section{Pola Perkampungan}

Pada zaman pendudukan Kolonial Hindia Belanda dulu, wilayah Parongpong merupakan bagian kecil dari wilayah perkebunan kopi yang dibudidayakan oleh Belanda di tanah Priangan. Pada masa itu, wilayah Parongpong pun dijadikan tempat penyerahan kuda-kuda dari luar negeri, yang akan digunakan para kontroler Belanda memeriksa tanaman kopi. Oleh karena banyaknya kuda, wilayah tersebut diumpamakan parungpung nyiruan oleh pribumi. Parungpung dalam bahasa Sunda berarti tempat nyayang nyiruan 'tempat bersarang lebah'. Kata parungpung dalam bahasa Belanda dituliskan paroongpoong. Penulisan tersebut lama kelamaan oleh masyarakat setempat dibaca parongpong.
Akan halnya nama Cihideung berasal dari kata caina hideung (bahasa Sunda) yang berarti airnya hitam. Dulu orang-orang di daerah tersebur giginya kuning karena caina peureu (caina haseum, kesed) dari pusat airnya (di Ciburial).

Tidak hanya kopi yang dibudidayakan Pemerintahan Kolonial Hindia Belanda, tetapi juga teh. Demikian perkebunan kopi pun di wilayah Parongpong sebagian berangsur-angsur menjadi lahan perkebunan teh, hingga sekarang dapat dijumpai Perkebunan Teh Sukawana milik PT Perkebunan Nusantara VIII. Selanjutnya peternakan sapi perah juga dikembangkan oleh Pemerintahan Hindia Belanda. Bahkan dalam tulisannya, Haryoto Kunto (1985) menyebutkan peternakan sapi perah, tepatnya di daerah Cisarua (di dekat wilayah Parongpong) menjadi terkenal karena merupakan salah satu "cikal bakal" usaha peternakan sapi perah dari jenis unggul yang didatangkan dari Friensland, Belanda. Nama perusahaannya adalah "Generaal de Wet Hoeve" milik Tuan Hirschiand dan Van Zijll di Cisarua.

Perkembangan selanjutnya, dari perkebunan kopi, teh, kemudian lahanlahan yang tersisa dimanfaatkan untuk pertanian sayuran dan buah-buahan, bahkan menjadi lahan-lahan untuk peternakan ayam, kelinci, dan sebagainya. Perkembangan penduduk pun semakin berkembang dengan pembukaan lahan untuk permukiman.

Pola perkampungan masyarakat Desa Cihideung, umumnya Kecamatan Parongpong berderet atau berkelompok dengan sesama kerabatnya. Pola berderet adalah pola yang dipergunakan penduduk yang berdiam di perkampungan di sepanjang jalan raya. Adapun 
pola berkelompok biasanya dengan sesama kerabatnya. Rumah-rumahnya menghadap ke jalan desa yang bercabang. Bentuk rumah pada umumnya sudah permanen, yaitu sekitar 4.010 rumah dengan kelengkapan sudah memiliki TV dan barang elektronik lainnya.

Sebagai daerah berdataran tinggi/ pegunungan yang subur, potensi air dan sumber daya air yang dimiliki adalah sungai dan mata air dengan debit masingmasing besar. Kedua sumber tersebut dimanfaatkan penduduk untuk memenuhi kebutuhan pertanian dan kehidupan sehari-hari mereka. Pemanfaatan sumber air bersih oleh penduduk didapatkan melalui sumur gali, PAM, dan mata air. Penduduk yang memanfaatkan sumur gali adalah sebanyak $285 \mathrm{KK}$, PAM sebanyak $874 \mathrm{KK}$, dan mata air sebanyak 4.391 KK 9 (Data Tingkat Perkembangan Desa dan Kelurahan Cihideung, 2009). Dari data tersebut, terlihat bahwa mayoritas penduduk memanfaatkan mata air di daerahnya untuk memenuhi kebutuhan hidupnya.

\section{Kependudukan}

Desa Cihideung berpenduduk 12.912 jiwa, yang terdiri atas 6.150 jiwa laki-laki dan 6.762 jiwa perempuan. Semuanya terbagi dalam $4.258 \mathrm{KK}$. Dari jumlah dan luas wilayah, dapatlah diketahui kepadatan penduduk per km, yaitu 344 orang. Sesuai dengan keadaan lingkungan alamnya, mata pencaharian penduduk Desa Cihideung mayoritas sebagai petani, sebanyak 1.187 orang

Keberagaman pendidikan penduduk masyarakat di Cihideung tentunya didukung oleh prasarana dan sarana pendidikan yang ada di lingkungan sekitar wilayah Kecamatan Parongpong, terutama untuk sekolah tingkat TK hingga SMA/sederajat. Prasarana yang ada adalah gedung SMA/sederajat 1 buah, SMP/sederajat 1 buah, SD/sederajat 8 buah, TK sebanyak 10 buah, gedung tempat bermain anak-anak 5 buah, dan Lembaga Pendidikan sebanyak 17 buah.

\section{Kehidupan Sosial Budaya}

Begitu terkenalnya tanaman hias dari Cihideung hingga kemudian daerah ini menjadi salah satu tujuan wisata yang populer di bilahan Kabupaten Bandung Barat; bagi masyarakat Desa Cihideung, hal itu merupakan anugrah dari Sang Pencipta. Untuk mengucapkan rasa syukur atas anugrah tersebut, mereka mewujudkannya dalam Cihideung Festival yang digelar di Kampung Kancah. Selain beberapa ritual untuk melestarikan alam, Cihideung Festival juga disemarakkan dengan berbagai lomba dan karnaval yang diikuti oleh RW-RW yang ada di desa tersebut.

Untuk mengenal sistem kepercayaan yang dimiliki warga masyarakat Desa Cihideung, dapat dilihat pada keyakinan mereka dalam menjaga hubungan yang harmonis dengan entitas supranarural. Entitas supranatural menurut pandangan mereka terdiri atas Tuhan dan para leluhur. Sistem keyakinan tersebut begitu lekat di hampir semua aktivitas kehidupan warga, baik aktivitas ekonomi, sosial, adat istiadat, maupun sistem kepemimpinan.

Warga Desa Cihideung mayoritas beragama Islam. Aktivitas keagamaan banyak mengisi hidup keseharian mereka, seperti kegiatan pengajian yang diikuti anak-anak dan para ibu. Pada hari-hari besar Islam, seperti Rajaban dan Maulud Nabi, mereka peringati dengan menghadirkan penceramah agama dari 
lingkungan desa mereka maupun dari luar desa.

Walau warga Desa Cihideung banyak yang beragama Islam, namun dalam kehidupan sehari-harinya masih diwarnai aturan-aturan adat yang menjadi kekayaan spiritul mereka. Kedua keyakinan tersebut sama-sama dijalankan dan berjalan berdampingan. Sehingga dalam suatu kegiatan ritual, bentuk yang mengemuka merupakan sinkretisasi dari kedua unsur tadi.

Warga Desa Cihideung yang memiliki sistem kepercayaan warisan dari leluhur, memiliki pandangan tersendiri tentang konsep alam dan manusa. Alam, dalam konsep kosmologi mereka dibagi menjadi dua, yaitu alam dunia dan alam gaib. Alam dunia atau alam nyata dihuni oleh makhluk hidup, seperti halnya manusia, binatang, tumbuh-tumbuhan, termasuk benda-benda nyata yang dapat dilihat. Adapun alam gaib adalah alam yang dihuni oleh makhluk-makhluk halus seperti ruh para karuhun, jin, setan, dan para hantu atau dedemit. Selain itu mereka pun mempercayai adanya ruh-ruh suci yang menguasai tempattempat maupun benda-benda tertentu yang berkaitan erat dengan kehidupan manusia, seperti yang menghuni Sirah Bangawan yaitu Ibu Inang Saketi, Ibu Dayang Sumbi, Ibu Lametan, Eyang Prabu Susuk Tunggal, Eyang Putih, dan lain-lain.

Menurut keyakinan mereka, manusia dapat melakukan kontak dan menjalin komunikasi dengan makhlukmakhluk halus di atas. Seperti halnya ruh para leluhur yang bisa diundang untuk dimintai bantuannya. Sebaliknya, ruh para leluhur dapat mendatangkan musibah berupa bencana dan malapetaka bagi mereka, bila larangannya dilanggar.
Itulah sebabnya, warga selalu memelihara hubungan mereka dengan ruh leluhur melalui berbagai ritual adat yang rutin dilaksanakan.

Kegiatan ritual dalam bentuk upacara adat diadakan dalam waktuwaktu tertentu dan rutin dilaksanakan adalah demi terjaminnya kepatuhan para warga terhadap pranata-pranata sosial. Bentuk-bentuk upacara tersebut tampak selain adanya keyakinan kepada Maha Pencipta juga keyakinan akan adanya dunia gaib. Dunia gaib yang sulit dijangkau akal manusia, yang ditempati makhluk-makhluk halus yang kekuatannya dapat berguna atau menimbulkan bencana atau mala petaka. Makhluk halus dapat berupa roh baik, roh jahat, hantu, jin. Roh yang baik antara lain adalah roh nenek moyang/leluhur atau karuhun. Pelaksanaan upacara adat selain dimaksudkan untuk memohon berkah kepada yang gaib, juga untuk menjalin hubungan baik sehingga tidak mengganggu mereka.

Sebagaimana masyarakat agraris pada umumnya, masyarakat Desa Cihideung pun memiliki upacara adat yang terkait dengan kesuburan tanah. Upacara tersebut merupakan sisa kepercayaan leluhur yang masih diyakini mereka, yaitu Ngaruat Solokan atau Hajat Cai. Ruatan Solokan adalah tradisi ritual untuk memelihara mata air dan selokan. Mereka memohon kepada Allah, karuhun, dan penunggu mata air agar air selalu dalam keadaan lancar.

Upacara tradisional lainnya yang kerap dilaksanakan warga adalah upacaraupacara yang berkaitan dengan daur hidup, seperti Upacara Tujuh Bulanan, Marhabaan (syukuran ketika bayi berusia 40 hari), Gusaran, Saparan, Nyepitan 
(khitanan), pernikahan, dan kematian; Upacara 14 Maulud, Upacara Syawalan.

Masyarakat Cihideung pun memiliki upacara adat yang berkaitan dengan peristiwa alam atau bencana alam, yaitu Ngabungbang (malam 14) dan Ruwat Kampung. Upacara Ngabungbang dilakukan pada malam tanggal 14 ketika bulan purnama. Warga berduyunduyun menyusuri pancuran, mulai dari Cisitu, Cijompo, Panggaladahan, hingga Cisiruan. Mereka mandi malam hingga tujuh kali di pancuran nu mayun ngaler sareng mayun ngetan 'yang menghadap utara dan menghadap barat' dengan harapan badan ingin sehat, dipanjangkan usia, dan diselamatkan dari mara bahaya. Ruwat Kampung adalah upacara yang dilaksanakan pada bulam Muharam, merupakan upacara tolak bala, yang bertujuan untuk mencegah lingkungan serta warga masyarakat dari datangnya gangguan dan penyakit, yang setiap saat dapat saja mengincar kehidupan mereka.

Selain mengenal berbagai upacara adat di atas, dalam kehidupan sehariharinya masyarakat Desa Cihideung pun akrab dengan berbagai larangan atau tabu yang ditetapkan leluhur mereka. Mereka patuh pada aturan-aturan tersebut, yang diyakini semua itu untuk kelancaran dan keharmonisan kehidupan mereka juga.

Bahasa Sunda adalah bahasa pengantar sehari-hari warga Cihideung dalam berkomunkasi dengan sesama warganya. Struktur bahasa yang mereka kenal adalah bahasa lemes 'halus' dan bahasa wanoh 'kasar'. Bahasa lemes digunakan seseorang ketika berbicara dengan orang yang usianya lebih tua dan dengan tamu yang datang dari luar desa. Akan halnya bahasa wanoh digunakan seseorang ketika berbicara dengan orangorang sebayanya. Bahasa Indonesia pun acapkali warga gunakan untuk betbicara dengan tamu yang datang, yang tidak mengerti bahasa Sunda.

Masyarakat Cihideung termasuk masyarakat yang begitu menghargai kesenian tradisional Sunda. Hal itu terbukti dengan masih setianya mereka memelihara kesenian tradisional Sunda. Para orang tua sebagai generasi tua telah mampu membina dan memberi motivasi kepada generasi muda untuk mencintai dan memelihara berbagai jenis kesenian yang ada atau yang sering tampil di desa mereka.

Keakraban mereka akan keberadaan kesenian tersebut tak lepas dari peranan sejumlah upacara adat tradisional yang hidup di sana, yang senantiasa menyertakan kesenian sebagai bagian dari rangkaian acara pada satu upacara. Beberapa kesenian ada yang dipertunjukkan khusus untuk menghibur masyarakat - biasanya disebut sebagai seni pertunjukan, yaitu Kuda Lumping, Barongsay, Singa Depok, Pencak Silat, Sasapian, Babagongan. Selain dalam upacara-upacara adat, kesenian tersebut pun sering dipergelarkan dalam acaraacara hajatan dan syukuran, seperti perkawinan, khitanan, peringatan harihari besar Nasional.

\section{Sejarah Upacara}

Air adalah sumber kehidupan yang paling vital bagi manusia. Bagi masyarakat agraris, selain untuk kebutuhan hidup sehari-hari, air pun digunakan untuk kebutuhan pertaniannya. Dekat wilayah Desa Cihideung terdapat mata air yang dikenal masyarakat dengan nama Mata Air Talaga Warna. Untuk melindungi keberadaan mata air ini, oleh orang Belanda dulu di sekeliling mata 
air dibuatkan tembok beton. Mata air pun kemudian digunakan mereka untuk kebutuhan perkebunan tehnya, yang dikenal Kebun Teh Pangheotan.

Kebun Teh Pangheotan di Sukawana terletak di Kampung Kancah Desa Karyawangi, Kecamatan Parongpong, Bandung Barat. Jaraknya 34 kilometer dari Kota Bandung, ke arah barat laut. Kebun Pangheotan didirikan pada tahun 1908 oleh Perusahaan Hindia Belanda. Sampai dengan periode 1957, kebun ini berada di bawah penguasaan HIL Tiedeman \& Van Kerchem yang berkedudukan di Bandung. Tercatat dua administratur Belanda yang bertugas di kebun itu, yakni Jan Willem Ruyssenaers (1927 - 1941) dan Albert Johan Ruyssenaers (1941 - 1957). Pada 1958, Kebun Teh Pangheotan dinasionalisasi menjadi milik Pemerintah RI dengan nama Perusahaan Perkebunan Negara (PPN) Lama. Berganti nama menjadi PPN Baru, PNP, dan pada 31 Juli 1971 dengan akta notaris HGS Loemban Tobing $\mathrm{SH}$, berubah lagi menjadi perusahaan perseroan PT Perkebunan XII yang berkedudukan di Bandung. Sejak 11 Maret 1996, PTP XII dilebur bersama PTP XI dan PTP XIII menjadi PT Perkebunan Nusantara VIII (PTPN VIII). Kebun Teh Pangheotan dikenal sebagai penghasil teh hitam (www.potlotadventure/2009/11/21/pilihan-barukebun-teh-pangheotan).

Pada tahun 1950-an, mata air diminta dari Belanda (Perkebunan Teh Sukawana) oleh para petani, terutama petani Cina untuk mengairi lahan pertanian mereka. Kemudian pada tahun 1970-an, manakala para petani Cina sudah tak ada karena telah beralih profesi, tidak lagi menjadi seorang petani, warga sekitar banyak yang mengeluh kesulitan air. Tidak hanya kesulitan air untuk lahan pertanian mereka, warga pun kesulitan air untuk kebutuhan hidup sehari-hari. Melalui musyawarah dengan para sesepuh masyarakat, mereka pun meminta izin kepada pemilik wilayah mata air guna memanfaatkan mata air tersebut untuk memenuhi kebutuhan pertanian dan hidup sehari-hari mereka. Keluarga keturunan pemilik lahan mempersilakan, jika memang mata air tersebut tidak digunakan oleh pengelola perkebunan.

Akhirnya, dengan biaya seadanya hasil pinjaman dari penyandang dana, mata air disalurkan ke warga-warga dengan menggunakan paralon (yang paling murah) sepanjang $3 \mathrm{~km}$. Setelah tuntas membuat saluran, dana yang digunakan dari hasil pinjaman tersebut harus ditanggung oleh warga. Ditetapkan pada saat itu, beban per bulan setiap KK adalah Rp. 500,-. Dana yang telah digunakan adalah untuk pembelian paralon dan honor para tukang. Menurut sesepuh, pinjaman tersebut dapat terlunasi sekitar 2 tahun lamanya. Hingga kini warga yang memanfaatkan mata air untuk memenuhi kebutuhan hidup sehari-hari tersebut sebanyak $600 \mathrm{KK}$ yang terbagi dalam 6 RT.

Warga benar-benar sangat bersyukur dengan limpahan air yang mereka terima sehingga bisa bercocok tanam palawija, sayuran, serta memenuhi kebutuhan lainnya. Sebagai ungkapan rasa syukur kepada Maha Pencipta serta untuk mengenang dan menghormati para leluhur mereka yang telah berjasa mengelola mata air, warga mengadakan Syukuran Cai atau dikenal dengan sebutan Hajat Cai atau Ngaruwat Solokan setiap tahun. 


\section{Nama Upacara dan Tahap- tahapannya}

Ngaruwat Solokan atau masyarakat lebih sering menyebutnya sebagai Hajat Cai atau Syukuran Cai adalah upacara tradisional yang diselenggarakan secara turun - temurun dilakukan setiap tahun olehmasyarakatpetanidiDesaCihideung, Kecamatan Parongpong. Mereka percaya bahwa air, salah satu unsur alam yang diciptakan Tuhan, berfungsi sebagai sumber kehidupan juga dapat membawa berkah bila warga masyarakatnya pandai memelihara dan melestarikannya.

Terkait dengan hal tersebut di atas, sumber mata air yang oleh warga setempat dipandang sebagai sumber kehidupan sekaligus membawa berkah bagi warganya, sangat dikeramatkan. Sumber mata air dimaksud adalah Talaga Warna. Sumber mata air Talaga Warna yang berlokasi di atas perbukitan dari pemukiman penduduk ini telah dimanfaatkan oleh $600 \mathrm{KK}$ yang terangkum dalam $2 \mathrm{RW}$.

Ngaruwat Solokan memiliki makna ngaruwat yang berarti memelihara atau merawat; dan solokan berarti jalan air. Dapatlah dikatakan bahwa istilah ngaruwat solokan memiliki arti ngarawat (memelihara) jalan air atau selokan agar terhindar dari kerusakan, sekaligus sebagai ucapan syukur atas limpahan air yang mereka nikmati selama ini. Adapun Hajat Cai memiliki makna hajat yang berarti mengadakan selamatan, dan cai (bahasa Sunda) berarti air. Jadi, Hajat Cai berarti mengadakan selamatan atas limpahan air yang Allah S.W.T berikan kepada mereka. Syukuran Cai sendiri memiliki makna syukuran yang berarti mengucapkan terima kasih kepada Allah S.W.T dan cai berarti air. Jadi, Syukuran
Cai berarti mengucapkan terima kasih kepada Allah SWT atas pemberian nikmat berupa air kepada mereka.

Upacara Ngaruwat Solokan atau Hajat Cai yang dilaksanakan masyarakat Cihideung melalui tahapan-tahapan sebagai berikut: persiapan, pembuatan/ pengolahan sesajen, Ijab Kabul (pengesahan), dan doa.

\section{Maksud Penyelenggaraan Upacara}

Orang Sunda, seperti orang Indonesia pada umumnya berpandangan bahwa kehidupan manusia bukan hanya berlangsung di dunia ini saja, tapi juga di dunia sana setelah manusia meninggal. Pandangan tersebut telah mempengaruhi tingkah laku orang Sunda dengan kuat, terutama karena sebagian besar dari mereka beragama Islam yang mengajarkan bahwa setiap orang bertanggungjawab atas segala tingkah lakunya masing-masing. Perbuatan yang baik akan mendapatkan pahala di dunia ataupun di akhirat, sedangkan perbuatan yang kurang baik merupakan dosa yang harus ditanggung sendiri di dunia dan di akhirat.

Sehubungan dengan hal tersebut di atas, dalam kebudayaan orang Sunda, banyak petunjuk yang harus dilakukan dan yang tidak boleh dilakukan. Sebagai contoh, terdapat sebuah pepatah 'cageur bageur bener pinter', yang artinya sehat, baik hati, benar, pandai. Hal-hal yang dilarang banyak ditunjukkan oleh pepatah, salah satunya 'pamali'. Bagi mereka yang melanggar pamali akan mengalami kemalangan, yang sebenarnya didatangkan padanya agar ia sadar dan tidak akan berbuat demikian lagi.

Selain melakukan kewajibankewajiban yang berdasarkan agama, 
diwajibkan pula untuk melakukan 'tatali paranti' atau 'adat karuhun', kebiasaankebiasaan sakral yang diwariskan oleh nenek moyang kita, antara lain upacaraupacara tradisional. Hal demikian dilakukan agar hidup kita selamat lahir batin, dunia dan akhirat.

Penyelenggaran Upacara Ngaruwat Solokan atau Hajat Cai ini bertujuan sebagai ungkapan rasa syukur kepada Tuhan Yang Mahaesa atas limpahan karunia yang selama ini mereka terima dan nikmati serta sebagai permohonan berkah agar warga masyarakatnya dijauhkan dari segala cobaan dan marabahaya.

\section{Waktu Penyelenggaraan Upacara}

Upacara Ngaruwat Solokan atau Hajat Cai ini diselenggarakan setahun sekali dan dilaksanakan pada bulan Maulud atau Muharam dengan waktu yang tidak jatuh pada larangan bulan serta pada waktu kosongnya pun pada hari baik. Secara teknis upacara ini dimulai pukul 07.00 dan berakhir sekitar pukul 13.00 WIB.

\section{Tempat Penyelenggaraan Upacara}

Pelaksanaan Upacara Ngaruwat Solokan atau Hajat Cai dilakukan di rumah sesepuh dan di lokasi mata air Talaga Warna. Sebagai sesepuh dalam kegiatan upacara sekaligus sesepuh masyarakat juga, Pak R. setiap tahun mempersiapkan rumahnya dijadikan pusat pelaksanaan kegiatan Upacara Hajat Cai atau Syukuran Cai. Rumahnya yang besar dengan halaman yang luas dapat memfasilitasi berbagai kegiatan, baik persiapan maupun pelaksanaan kegiatan tersebut.
Rumah sesepuh sekitar sebulan sebelum pelaksanaan upacara terlihat mulai dikunjungi para sesepuh dan tokoh masyarakat lainnya untuk membahas berbagai langkah dalam persiapan melaksanakan Upacara Hajat Cai. Sekitar dua hari sebelum acara, di rumah sesepuh pun mulai disibukkan dengan persiapan yang dilakukan oleh para ibu yang akan mengolah makanan untuk perlengkapan sesaji dan menjamu para tamu.

Pada hari pelaksanaan upacara, sejak pagi di rumah sesepuh telah ramai dikunjungi orang-orang yang akan turut meramaikan acara. Mulai dari tim kesenian yang akan mengiringi arakarakan hingga para ibu, bapak, kaum muda, yang turut ambil bagian dalam arak-arakan dengan membawa nasi tumpeng dan makanan lainnya. Oleh karena jaraknya cukup jauh, arak-arakan menggunakan kendaraan bermotor hingga ke kaki bukit. Dari sana, mereka berjalan kaki menuju lokasi upacara.

Adapun puncak upacaranya diselenggarakan di mata air Talaga Warna, yang berada di perbukitan Perkebunan Teh Sukawana. Jaraknya sekitar $2 \mathrm{~km}$ dari pusat kegiatan. Lingkungan alam mata air Talaga Warna dibuat apa adanya, dalam artian alam lingkungannya tidak dirombak. Sebaliknya, beberapa puluh meter jalan kecil menuju ke sana sengaja dibuat rimbun dengan ditanami tanaman yang dedaunannya nyaris menutupi jalan. Hal itu sengaja dibuat agar mata air terjaga dari "tangan-tangan jahil". Jalanan tersebut terkesan alami karena di sekitarnya banyak tumbuhan tanaman liar. Ruas jalannya sempit dan menyisiri perbukitan yang curam dengan aliran sungai jauh di bawahnya.

Mata airnya sendiri sejak zaman Belanda sudah dilindungi dengan diberi 
tembok beton. Bangunan tembok kini ada lubangnya, yang sengaja pada tahun 1950-an dibobol oleh warga. Dari lubang, dapat terlihat genangan mata air yang jernih, bersih. Genangan air tampak tenang, tidak meluap-luap, nyaris air terlihat dangkal. Menurut sesepuh, merupakan kebesaran Allah bahwa dari sumber mata air yang airnya keluar kecil, kemudian mengalir ke daerah yang lebih rendah dan dapat dimanfaatkan serta memenuhi kebutuhan hidup hampir 600 KK warga di sekitarnya.

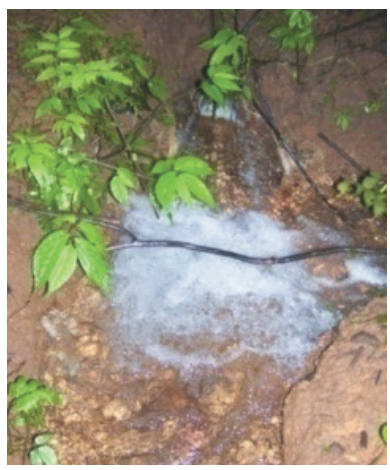

Sumber Mata Air Talaga Warna

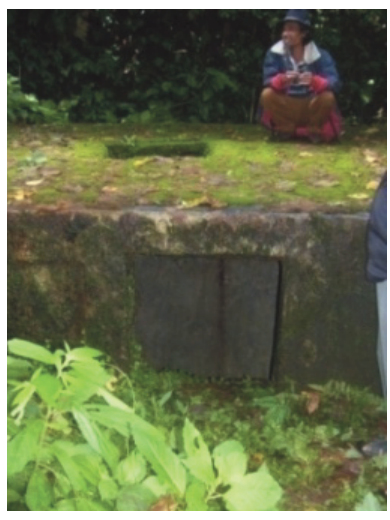

Tembok beton yang melindungi mata air

Sumber: Penelitian 2010

\section{Penyelenggaraan Teknis Upacara}

Sekitar sebulan sebelum Upacara Ngaruwat Solokan atau Hajat Cai atau Syukuran Cai dilaksanakan, pihak penyelenggara atau yang berkompeten dalam kegiatan tersebut berkumpul di rumah sesepuh untukmembahas berbagai langkah dalam persiapan melaksanakan upacara tersebut. Rapat yang dipimpin sesepuh itu, dihadiri antara lain oleh para tokoh adat, tokoh masyarakat, ketua RT, dan masyarakat petani pendukung upacara. Mereka membicarakan masalah kegiatan yang akan dilaksanakan, dimulai dari pembentukan panitia.

Setelah susunan kepanitian terbentuk, maka bendahara mulai melaksanakan tugasnya, yaitu merinci biaya pelaksanaan upacara serta mengumpulkan dana dari para donatur. Biaya yang dirinci antara lain untuk pembelian kelengkapan berupa sesajen, hiburan yang akan dipergelarkan, serta konsumsi panitia dan para undangan selama kegiatan tersebut berlangsung.

Dua hari sebelum pelaksanaan upacara, di rumah sesepuh yang dijadikan sebagai pusat pelaksanaan kegiatan telah ramai didatangi para ibu yang akan membantu mempersiapkan kelengkapan sesajen dan mengolah konsumsi untuk panitia dan para undangan nanti. Sementara itu kaum pria (para bapak dan pemuda) mempersiapkan lokasi mata air Talaga Warna dengan membersihkannya dari alang-alang dan tanaman merambat lainnya.

Sehari sebelum pelaksanaan upacara, kesibukan semakin terlihat di rumah sesepuh. Panitia dan orang-orang yang terkait dalam kegiatan ini mulai melakukan pengecekan akan tugasnya masing-masing. Pemasangan tenda, kursi, serta memeriksa kelengkapan alatalat kesenian yang akan ditampilkan pada keesokan harinya.

Tak hanya itu, panitia pun memeriksa kesiapan para petugas Upacara Ngaruwat Solokan atau Hajat Cai, yaitu sesepuh (yang akan memberikan sambutan), petugas yang 
akan membacakan ayat suci Al-Quran, Lebe (petugas yang memimpin doa), dan Pawang (yang bertugas memimpin upacara).

\section{Pihak-pihak yang Terlibat dalam Upacara}

Setiap tahun pihak-pihak yang terlibat dalam kegiatan Upacara Ngaruwat Solokan atau Hajat Cai pada dasarnya sama, yaitu pihak-pihak yang terlibat dalam upacara sebagai tamu atau undangan yaitu Kepala Desa beserta beberapa aparatnya dan Lebe; serta pihakpihak yang terlibat langsung sebagai pelaku atau pendukung upacara yaitu warga masyarakat setempat, khususnya para petani baik sebagai tokoh adat, tokoh masyarakat, dan kaum laki - laki serta perempuan.

Kedua unsur tersebut di atas baik langsung maupun tidak langsung berperan dalam proses pelaksanaan penyelenggaraan upacara. Mereka saling membantu dan melengkapi satu sama lain demi suksesnya penyelenggaraan Upacara Ngaruwat Solokan atau Hajat Cai yang diadakan di tempat mereka.

\section{Persiapan dan Perlengkapan Upacara}

Beberapa kegiatan sebagai persiapan dalammenghadapi pelaksanaan Upacara Ngaruwat Solokan atau Hajat Cai, terutama yang berkaitan dengan perlengkapan, tempat, pelaksana, dan pendukung upacara lainnya dilakukan oleh kaum perempuan (para ibu dan pemudi) serta kaum pria (para bapak dan pemuda). Mereka bekerja bersama, bergotong royong guna lancarnya acara yang mereka nanti-nantikan.
Dua hari sebelum acara dilaksanakan, kaum ibu umumnya berbelanja membeli bahan-bahan makanan, buah-buahan, serta perlengkapan untuk sesajen. Sehari sebelum acara, mereka mengolah makanan, membuat tumpeng, makanan kecil untuk para undangan dan peserta upacara.

Kelengkapan sesajen berupa surutu 'cerutu', roko bodas 'rokok putih', bako tampang, bako molen, madat (bako hideung), daun kawung dilinting 'digulung' dan diikat (jangan sampai dilipat ujungnya karena dianggap pamali), lemareun sakumplitna 'bahan untuk menginang selengkapnya', telur ayam, dawegan, hahampangan (ada tangkue), pisang kapas bakar, beras dan telur di sekelilingnya diletakkan uang logam Rp.100,00 sebanyak 10 buah, kembang ros merah, putih, campaka mulia, minyak air mata duyung, buahbuahan seperti apel, anggur, belimbing, pir; serta makanan olahan berupa bakakak hayam hideung, rurujakan tujuh macam, kopi pahit, kopi manis, air teh, air putih, bajigur, susu, gula merah kawung asli, 6 puncak manik nasi kuning, nasi tumpeng yang diolah oleh kaum ibu. Selain itu kelengkapan pedupaan pun disediakan, seperti arang dan kemenyan.

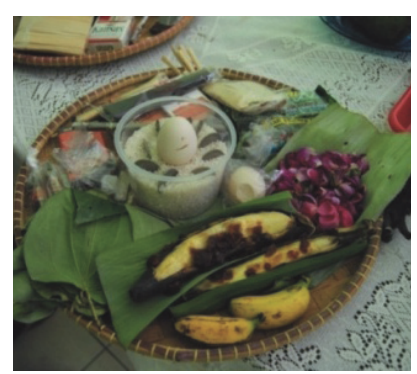

Sesajen di atas tampah 


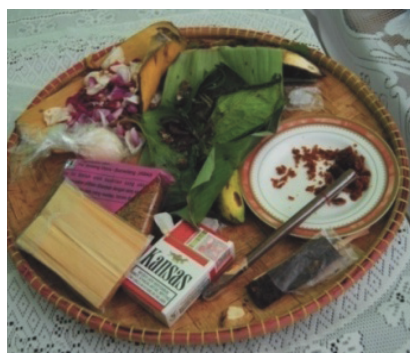

Sesajen yang penuh makna Sumber: Penelitian 2010

Pada malam hari menjelang Upacara Ngaruwat Solokan atau Hajat Cai dilaksanakan, yakni sekitar pukul 20.00 WIB, sesajen tersebut di atas diijab kabul oleh pawang, sebagai tanda bahwa sesajen itu telah memenuhi persyaratan (lengkap) dan sah untuk dipersembahkan dalam Upacara Ngaruwat Solokan atau Hajat Cai. Sesaji tersebut ditujukan untuk para karuhun (leluhur) yang dianggap sebagai media atau penghubung kepada Tuhan Yang Mahaesa.

Sementara itu kaum pria mempersiapkan tenda, kursi, serta membersihkan lokasi di sekitar Mata Air Talaga Warna. Tak hanya itu, kaum pria yang terlibat sebagai panitia pun mengecek kesiapan para tokoh pelaksana upacara serta tim kesenian yang akan mengiringi sekaligus menghibur para peserta upacara dan warga sekitar.

Pada pagi hari pelaksanaan upacara, bahan-bahan sesajen tersebut di atas telah dipersiapkan. Beberapa jenis sesajen diberi wadah berupa piring kecil dan beberapa dialasi daun pisang, kemudian ditata pada sebuah nyiru 'sejenis tampah yang terbuat dari anyaman bambu'.

\section{Jalannya Upacara Selengkapnya}

Pada hari pelaksanaan upacara, mulai pukul 07.00 orang-orang berduyunduyun berdatangan menuju tempat pusat kegiatan upacara, yaitu rumah sesepuh. Beberapa para ibu membawa makanan, baik berupa tumpeng maupun buahbuahan seperti pisang. Sementara itu tim kesenian telah bersiap-siap pula ntuk turut serta dalam iringan rombongan menuju ke lokasi mata air Talaga Warna.

Sebelum berangkat ke lokasi mata air, acara dibuka dengan pembacaan ayat suci Al-Quran terlebih dahulu. Dilanjutkan kemudian dengan acara sambutan dari sesepuh sebagai tuan rumah, tokoh masyarakat, dan Ketua RW.

Selesai acara pembukaan dilanjutkan kemudian dengan persiapan iring-iringan rombongan yang akan menuju lokasi mata air. Iringan terdepan adalah enam orang penari yang membawa enam pucuk manik. Diikuti kemudian di belakangnya beberapa orang laki-laki yang membawa sesajen dengan cara dipikul, para sesepuh, tokoh masyarakat, para undangan, dan para ibu/bapa yang membawa makanan.

Tiba di tempat tujuan (Mata Air Talaga Warna), enam pucuk manik diterima oleh lengser beserta sesajen dan makanan. Sesajen ditata dan ditempatkan pada suatu tempat yang telah ditentukan. Kemudian dupa yang berisi arang dinyalakan, dan kemenyan ditaburkan di atas dupa.

Para peserta pendukung upacara semua duduk berkumpul dengan formasi melingkar secara sentral ke arah sesajen. Pawang duduk bersila dengan sesajen di depannya. Ia pun membuka cerutu dan rokok. Dilanjutkan kemudian membacakan ijab kabul sambil menyalakan cerutu dan rokok tersebut. Pawang melakukan ijab kabul dengan para karuhun, yaitu Dayang Sumbi, Eyang Prabu Susuk Tunggal, Eyang 
Putih, dan Eyang Ngameta. Pawang pun memanjatkan doa kepada Yang Maha Kuasa. Inti dari doa tersebut adalah mengucapkan syukur kepada Tuhan Yang Mahaesa dan memohon berkah serta keselamatan bagi warga desa agar kehidupan di masa mendatang berjalan lebih baik tanpa ada gangguan apa pun.

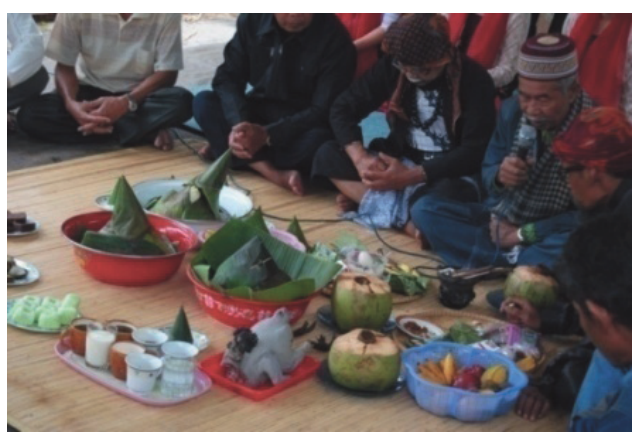

Pawang sedang mengucapkan ijab kabul Sumber: Penelitian 2010

Usai melakukan ijab kabul, Pawang menyampaikan sambutan. Ia mengucapkan syukur dan ucapan terima kasih kepada penyelenggara Upacara Ngaruwat Solokan atau Hajat Cai. Ia pun menyampaikan maksud dan tujuan dari upacara tersebut, yaitu sebagai ungkapan rasa syukur kepada Allah SWT atas rezeki yang diberikan berupa air. Air yang dilimpahkan ke daerah ini, mudahmudahan bermanfaat bagi warga semua. Dan diadakan upacara ini adalah untuk menyelamatkan semuanya, manjangkeun 'memanjangkan' nikmat dari Allah.

Setelah ijab kabul, dilanjutkan kemudian Pawang menyalakan obor dengan diiringi kidung, yaitu Kidung, Kembang Gadung, dan Buah Kawung. Tujuh pucuk manik pun dan pedupaan diletakkan dibawahobor. Berikut Kidung, yang intinya memohon doa kepada Yang
Maha Kuasa serta memohon izin kepada para leluhur untuk melaksanakan acara.

\section{KIDUNG :}

Bulkukus mancur kamanggung / Ka dewa para pohaci / Ka batara sang dewata / Sanghiang Dewi Pertiwi / Ka buana panca tengah / Jembarna ka maha suci // Neda agung sampurasun / Kasa eui ning dedemit / Bara hala duru wiksa / Mugi ulah hiri dengki / Sing sami-sami ngajadi / Ngajaring hiang pertiwi / Nu ti kulon nu ti wetan / Nu tetepis wiring basisir / Nu ti kaler nu ti kidul / Suku gunung lamping asih / Nu ngageugeuh panca tengah / Putra-putri mugi dijaring.

Acara dilanjutkan dengan sambutan dari aparat pemerintahan. Setelah itu Pawang menguraikan makna dari setiap jenis sesajen kepada para peserta upacara, dan diakhiri dengan doa bersama. Prosesi upacara di sumber mata air Telaga Warna di atas dimulai sekitar pukul 09.00 sampai 11.00 WIB. Acara diakhiri dengan acara ramah tamah dan makan bersama. Acara hiburan pun dipergelarkan, mengiringi acara makan bersama.

\section{Pantangan yang Terkandung dalam Upacara}

Pantangan yang harus ditaati oleh para pelaksana Upacara Ngaruwat Solokan atau Hajat Cai, antara lain : Sesajen khusus yang terbuat dari masakan olahan, tidak boleh dibuat oleh ibu-ibu yang sedang datang bulan; sesajen yang sudah disahkan (ijab kabul) tidak boleh dicicipi; sesajen tidak ada yang boleh kurang (tidak lengkap); dan tidak boleh bersuara sewaktu upacara berlangsung. Apabila pantangan-pantangan yang telah digariskan secara turun temurun 
itu dilanggar, maka hajatnya tidak akan diterima, bahkan petaka akan menimpanya.

\section{Makna yang Terkandung dalam Unsur Upacara}

Unsur-unsur yang ada pada Upacara Ngaruwat Solokan atau Hajat Cai merupakan simbol untuk dikaji agar hidup tidak salah langkah. Intinya adalah di dalam unsur-unsur upacara terdapat nilai luhur kearifan lokal yang dijadikan pedoman pandangan hidup agar kita tidak salah dalam melangkah. Berikut unsur-unsur dalam upacara yang memiliki makna, yaitu :

a. Warna merah dari bara api, melambangkan keberanian, maksudnya warga masyarakat setempat berani berkorban baik materi maupun nonmateri yang dimilikinya demi menjalankan perintah adat leluhurnya.

b. Parukuyan 'pedupaan' dan menyan 'kemenyan'.Parukuyanataupedupaan adalah tempat arang/bara api yang terbuat dari tanah, yang diibaratkan sebagai tempat sari pati dari sekujur tubuh. Merah, melambangkan api; kuning, melambangkan angin; putih melambangkan air; dan hitam melambangkan tanah. Maknanya bahwa saripati dari api, angin, air, dan tanah adalah asal dari sekujur tubuh/penopang hidup. Menyan atau kemenyan:tementurnyaan/nuenyana/ sa enya-enyana 'bukan main-main, sungguh-sungguh'. Maknanya, dalam penelusuran/kajian/penghayatannya harus secara sungguh-sungguh dan sebenar- benarnya.

Kemenyan dibakar dalam parukuyan 'pedupaan'. Proses ini akan menimbulkan kepulan asap yang membumbung ke atas dan menimbulkan aroma yang khas. Menurut kepercayaan mereka bahwa penguasa alam adanya di atas. Oleh karena itu kepulan asap yang membumbung ke atas itu berfungsi sebagai lambang komunikasi antara manusia yang ada di bawah dengan penguasa alam yang berada di atas. Sedangkan aroma harum, wangi yang berasal dari kemenyan itu menandakan penghormatan kepada penguasa alam.

c. Kembang tujuh rupa nu seungit 'tujuh jenis bunga yang wangi', yang dijadikan sesajen merupakan simbol bilangan. Bilangan tujuh, melambangkan jumlah hari. Hal ini yang dimaksudkan agar warga masyarakat dalam kesehariannya harus berbuat baik, sehingga namanya sampai kapan pun tetap dikenang (harum). Apabila manusia menginginkan penghasilan yang lebih baik lagi, maka ia harus banyak bersedekah setiap harinya. Selain itu tujuh juga menunjukkan tujuh kuasa yang ada dalam diri : Kawasa, Kersa, Uninga, Hirup, Tingali, Ngarungu, dan Ngandika, yang merupakan Guru Hyang Tujuh yaitu tujuh kuasa yang ada pada diri yang berasal dari Tuhan. Kemudian bunga wangi memiliki makna : Geura kembangkeun/ mekarkeun/daya upayakeun eta pangawasa nu tujuh ku jalan silih seungitan ka sasama hirup 'Segera kembangkan tujuh kuasa tadi dengan jalan belas kasih ke sesama makhluk'.

d. Rujak tujuh rupa 'tujuh macam rujak'. Rujak memiliki rasa manis, pahit, asam, keset, dan lain-lain. 
Tujuh macam menunjukkan tujuh hari. Makna tujuh macam rujak adalah bahwa dalam tujuh hari kita mengalami berbagai rasa kehidupan.

e. Amparan/samak 'tikar'. Amparan/ samak, maknanya kudu saamparan, samaksud, satujuan 'harus satu alas dasar, satu maksud, satu tujuan'. Jadi, semua maksud dan tujuan harus didasari nilai-nilai $K a$ Tuhanan, Kamanusaan, Kabangsaan, Karahyatan, Kaadilan 'Ketuhanan, Kemanusiaan, Kebangsaan, Kerakyatan, Keadilan'.

f. Kopi pait, kopi amis, cai teh, susu, jeung cai asak herang 'kopi pahit, kopi manis, air teh, susu, dan air matang bening'. Maknanya dari aneka minuman tersebut adalah : Sajeroning lampah hirup pinasti ngaliwatan papait jeung mamanis nu sakuduna digodog, diasakan dina wening ati herang manah 'Dalam perjalanan hidup tentu melewati pahit manisnya kehidupan, yang sebaiknya direnungkan dalam kebersihan hati dan pikiran'.

g. Sangu tumpeng 'nasi tumpeng'. Maknanya adalah tumpuk tumpang ngajadi hiji sahingga mangpaat keur kahirupan urang, ulah rek pakiakia pagirang-girang tampian kawas remeh sumawur teu pararuguh 'menumpuk, menumpang menjadi satu sehingga bermanfaat untuk kehidupan kita, jangan hidup sendirisendiri seperti butiran nasi yang jatuh bertaburan dan sia-sia'.

h. Bakakak hayam hideung 'ayam bakakak hitam'. Maknanya adalah pasrah sumerah ka Gusti (tumamprak lir bakakak) 'pasrah kepada Allah SWT, layaknya seperti posisi ayam bakakak'. i. Puncak manik. Maknanya adalah puncak tina kahirupan nya eta silih ajenan ka sasama 'puncak dari kehidupan adalah saling menghargai antarsesama'.

j. Lemareun/seupaheun 'bahan untuk menginang selengkapnya'. Maknanya adalah mun urang rek ngucap, lumaku jeung lumampah ulah rek gurung gusuh tapi kudu di beuweung di utahkeun, persis nu nyeupah 'dalam berkata dan bertingkah laku jangan terburu-buru, tetapi harus dipertimbangkan dahulu seperti orang yang menginang'.

$k$. Mantra (rajah). Mantra atau rajah yang diucapkan oleh Pawang merupakan alat untuk menyampaikan maksud dan tujuan upacara adat. Sedangkan doa yang diucapkan merupakan alat untuk bersyukur kepada penguasa alam.

\section{PENUTUP}

Upacara Ngaruwat Solokan atau Hajat Cai di Desa Cihideung, Kecamatan Parongpong dilaksanakan dengan maksud sebagai ucapan rasa syukur atas limpahan rezeki dan pengharapan kehidupan yang lebih baik di masa mendatang. Ucapan rasa syukur tersebut ditujukan pada Sang Maha Pencipta, Tuhan Yang Mahaesa, serta kepada leluhur yang telah mewariskan lahan pertanian bagi kelanjutan kehidupan keturunannya.

Dari pelaksanaan Upacara Ngaruwat Solokan atau Hajat Cai yang hingga kini masih dilaksanakan oleh masyarakat para pendukungnya terkandung berbagai macam nilai budaya yang telah berlaku secara turun temurun dan berguna untuk mengukuhkan rasa solidaritas atau kebersamaan antarsesama 
warga masyarakat. Nilai-nilai budaya dimaksud antara lain:

a. Nilai religius, tampak dalam ritualritual yang senantiasa ditujukan untuk mengagungkan Tuhan Yang Mahaesa dan menghormati para leluhurnya.

b. Nilai sosial, tampak dalam keseluruhan upacara yang senantiasa dilakukan dengan cara gotong royong, saling membantu, saling berbagi, serta mengokohkan ikatan persaudaraan dan kekerabatan.

c. Nilai ekonomi. Dengan adanya upacara ini berarti selalu mengingatkan warga untuk menjaga dan memelihara lingkungan alam, terutama yang berhubungan dengan keberadaan mata air. Air yang melimpah dapat dikelola secara baik sehingga masyarakat dapat memperoleh nilai ekonomisnya.

d. Nilai pendidikan. Dalam prosesi upacara, Pawang selalu menerangkan maksud dan tujuan serta makna dari sesajen yang ada kepada peserta upacara. Makna dari unsur-unsur upacara merupakan pedoman perilaku bagi warga dalam kehidupan sehari-hari. Selain itu, secara tidak langsung pelaksanaan upacara pun memberi pembelajaran kepada generasi muda agar mereka senantiasa melestarikan budaya warisan leluhurnya;

e. Nilai rekreatif, dalam rangkaian upacara tradisional tersebut, unsur hiburan merupakan salah satu nilai yang bermanfaat bagi para petani setelah kesehariannya mereka bergelut dengan kegiatan rutin yang cukup keras dan melelahkan. Hal ini tampak dari sikap mereka yang sangat antusias dalam menikmati hiburan rakyat bersama para petani atau warga lainnya.

Mengingat saratnya nilai-nilaiyang terkandung dalam upacara tersebut, maka sudah selayaknya upacara tersebut terus dilestarikan, dibina, dan dikembangkan demi terwujudnya kebudayaan nasional yang utuh. Selain itu juga, dengan adanya kegiatan upacara tradisional pada suatu daerah tertentu akan menjadi daya tarik tersendiri bagi daerah tersebut sebagai salah satu tujuan wisata. Sudah tentu terlebih dahulu harus ada pembinaan dan pembenahan, sehingga pada akhirnya layak untuk dijadikan kalender kegiatan kepariwisataan.

\section{DAFTAR PUSTAKA}

Andayani S., Ria, dkk. 2005.

Budaya Spiritual Masyarakat Sunda. Bandung: Depbudpar BPSNT Bandung.

BPSNT Bandung. 2007.

Jurnal Penelitian Edisi 38/

Setember 2007. Bandung:

Depbudpar.

Kunto, Haryoto. 1985.

Wajah Bandoeng Tempo Dulu.

Bandung: PT Granesia.

Lembaga Basa \& Sastra Sunda. 1981

Kamus Umum Basa Sunda.

Bandung: Penerbit Tarate. 


\section{Laporan Penelitian}

Intani, Ria. 2002.

Upacara Mapag Sri di Kabupaten Majalengka. Bandung: Disbudpar.

Rusnanto, dkk. 2010.

Upacara Tradisional Rahengan di Desa Citatah Kecamatan Cipatat dan Upacara Hajat Cai di Desa Cihideung Kecamatan Parongpong Kabupaten Bandung Barat. Disbudpar Kabupaten Bandung Barat.

\section{Sumber Elektronik}

Ngaruwat Garut Selatan. Muhammad Zia Ulhaq.

id-id.facebook.com/topic.php?ui $d=270577024309 \&$ topic $=46066$

Ruwatan dalam Budaya Sunda. Eko Risanto.

e korisanto.blogs pot. com/2009/08//ruwatan-dalambudaya-Sunda-1.html

www.ratupelet.com/makna.ruwatan

www.potlot-adventure/2009/11/21/ pilihan-baru-kebun-tehpengheotan 